\title{
What is the effect of Organizational Justice and Perceived Organizational and Supervisor Support on Employee's Level of Trust?
}

\author{
Sadia Arif ${ }^{1 *}$, Ozair Kundi ${ }^{2}$, Muhammad Suleman Khan ${ }^{3}$ \\ ${ }^{1}$ COMSATS, Institute of Information technology, Islamabad, Pakistan \\ 2 Iqra University Islamabad, Pakistan \\ 3 Air University Islamabad, Pakistan \\ * Corresponding author: sadia@vcomsats.edu.pk
}

\begin{abstract}
Article History
Received 2019-11-26

Revised 2019-12-26

Revised 2020-01-15

Accepted 2020-01-20

Published 2020-01-20
\end{abstract}

\section{Keywords}

Organizational justice

Perceived organizational support

Perceived supervisor support

Trust

\section{How to cite?}

Arif, S., Kundi, U., \& Khan, M. S. (2020). What is the effect of

Organizational Justice and Perceived

Organizational and Supervisor Support on

Employee's Level of Trust? SEISENSE

Journal of Management, 3(2), 47-63.

doi:10.33215/sjom.v3i1.263

\section{Abstract}

Aim - Past studies support the importance of organizational justice and its impact on employees' work attitudes. There are many factors that affect the employees' work attitude but their perceptions about organizational justice and support are significant factors. Many studies have been conducted to investigate the relationship between Organizational justice and trust but there is lack of research to measure the mediating role of perceived support. This study examines the role of perceived support as a mediator between organizational justice and trust.

Methodology - Sample of study is 170 faculty members of public and private sector universities of Pakistan. A cross-sectional design with standardized questionnaire is used.

Findings - Results indicate that distributive, procedural and interactional justice is direct antecedents of organizational and supervisory trust with the demonstration perceived organizational support as a partial mediator between procedural justice and organizational trust. Distributive justice is related to organizational trust both directly and indirectly through perceived organizational support and supervisory trust. Finally, interactional justice is direct and indirect predictor of supervisory trust through perceived supervisor support. 


\section{Introduction}

Trust is just like air - we all give little consideration to it until it is not there. It is essential for sustaining individual and organizational effectiveness. Trust, like credibility, is a perishable commodity, for organizational survival and success it must be continuously nurtured and renewed.

A culture of trust is a valuable asset for any firm's success in long term, as it is an essential part of productive organizational relationships (Sousa-Lima, Michel, \& Caetano, 2013). Trust helps to build relationships, facilitates collaboration, increases organizational commitment, and employees' willingness to innovate (Hubbell \& Chory-Assad, 2005). Trust plays an important role in increasing the academicians' organizational citizenship behaviors (Ertürk, 2007) and these behaviors contribute to the effective functioning of an organization (Robbins, 2011).

Talking about the education sector and more specifically the educational institutes, which are mostly based on the values such as organizational commitment and the attitudes of employees towards that commitment. Faculty members are among the key people responsible for promoting the rich culture, economic development and social development of the society through their research and solutions for the problems prevailing in the society and to promote the importance of educational objectives by imparting the knowledge and training the individuals who will contribute directly towards the society. Effectiveness of the educational institutions depends upon the climate of trust in organization (Zeinabadi \& Rastegarpour, 2010). If we compare the picture of educational institutes with about generation ago and present, we will find the trust presence in culture at significant low level today.

Today's individuals are either not finding work or afraid of losing jobs and or not getting promotions or raises, Herzberg's motivating factors become much more important. Herzberg's Motivation - Hygiene theory states that there are certain work place intangibles or other motivational factors that are encouraging to employees to put their maximum efforts and upsurge organizational performance, if they are paid enough consideration.

Numerous research has been conducted on the relationship between perceived organizational justice, perceived supervisory support, trust in an organization, performance and turnover (DeConinck \& Johnson, 2009), but trust was not included. Future studies could expand the model by including other variables such as leadermember exchange or trust (both supervisory trust and organizational trust). Additionally, due to the fact most of these parameters are highly related, yet shocking to our knowledge only few studies incorporated all of these variables. Previous research showed the relationship between justice, support, and trust (DeConinck, 2010) and another included only two form of justice by ignoring the distributive justice (Stinglhamber, Cremer, \& Mercken, 2006) and also recommended that all the dimensions of justices is astonishing and urges the need for future research.

The purpose of the study aims to examines a very comprehensive model that incorporates all these variables: perceived support, organizational justice (distributive, procedural and interactional) and trust (organizational and supervisor), in a single study. This study will elaborate the previous work by studying the model that explores mediating role of perceived organizational and perceived supervisory support for the relationship of dimensions of organizational justice those are distributive justice, procedural justice and interactional justice and types of trust- organizational trust and supervisory trust. 


\section{Literature Review}

\section{Organizational Justice}

Organizational Justice is the employees' perceptions about perceive workplace processes, relations and consequences. Fairness is an important virtue of organization (Greenberg, 1990). Organizational justice identified employees' insights about how they were treated rightly and how these insights affect the organizational consequences such as commitment and satisfaction.

Substantial consideration has been directed at the dimension of the organizational justice (Niehoff \& Moorman, 1993). Three dimensions of Organizational justice: distributive, procedural as well as interactional (Bakhshi, Kumar, \& Rani, 2009).

\section{Distributive Justice}

Before 1975, the researchers were only concerned with distributive justice. It was defined as the extents to which rewards are distributed in a rightful way are known as distributive justice (Niehoff \& Moorman, 1993). Distributive justice is the perceived fairness of the outcomes that an employee develops from organizations (Folger \& Konovsky, 1989). Distributive justice explains the employees' reaction to the actions or distribution of rewards such as salary, extra benefits, up gradation, job safety and dismissals from the organization(Greenberg, 2001). This particular form of organizational justice emphases on people's opinions regarding to acquire fair amount of work related outcomes like pays, incentives, promotions etc. and also have impact on worker satisfaction with their work outcomes, such as remuneration as well as job responsibilities(Noruzy, Shatery, Rezazadeh, \& Hatami-Shirkouhi, 2011).

\section{Procedural Justice}

Procedural justice is the perceptions of employees about the fairness of the formal procedures by which outcomes are measured (Moliner, Martínez-Tur, Ramos, Peiró, \& Cropanzano, 2008). Researchers argued that procedural justice refers to fairness in procedures used in decision-making about advancement, performance appraisal, bonuses and other organizational opportunities (Shanock \& Eisenberger, 2006).

A key feature in procedural justice is usually permitting members to have a say in decision making or to have inputs in outcomes and get feedback. Therefore, whether or not the actual end result is usually unsatisfactory to participants, considering their views in process making can reduce dissatisfaction. Distributive justice is associated with specific outcome like pay, whereas procedural justice is related to organizational consequences like commitment to organization and citizenship behavior (Colquitt, Conlon, Wesson, Porter, \& Ng, 2001).

Studies argued that procedural justice refers to fairness in procedures used in decision-making about advancement, performance appraisal, bonuses and other organizational opportunities(Roch \& Shanock, 2006).

\section{Interactional justice}

Interactional justice is interpersonal handling or level of perceived equality in how workers are treated in organization (Bies \& Shapiro, 1987).

Previous researchers found that fairness of the interpersonal behavior and communication is considered by the people (Ambrose, 2002). Interactional justice is less formalized in terms of communication as compare to procedural justice. It revolves around the management's behaviors like degree of sincerity and respect towards subordinates. When it comes to the procedural justice the issues related to perception of injustice are directed upon the organization. Nonetheless, when it comes to the perceptions of interactional injustice, it is directed towards the supervisor (Masterson, Lewis, Goldman, \& Taylor, 2000). 


\section{Perceived Organizational Support (POS)}

To have a better insight on the relationship between the employee and employer exchange relationship, researchers proposed a theory which was based on the concept of social exchange called perceived organizational support theory (Eisenberger, Huntington, Hutchison, \& Sowa, 1986). Organizational support theory (OST) suggest that employee over the time develop certain perception about the organization in which it works that either the organization pay enough care towards that employee wellbeing or care for them or value their input that employee give (Kurtessis et al., 2015).

\section{Perceived Supervisory Support (PSS)}

In the recent times the literature shows that perceived supervisory support has got enough attention and it is found to be significantly related to the organizational outcomes. Employees pay attention to the behavior of their supervisor as how he or she pay attention to them or care for them or care for their well-being and appreciate their contribution towards the organization(Maertz, Griffeth, Campbell, \& Allen, 2007).

\section{Trust}

Trust is usually a significant portion of social exchanges due to the fact when anyone comes with a help to an alternative particular person, anyone ought to trust of which the other person will reciprocate (Blau, 1964). Confidence makes it possible for individuals to take risk. While one particular party invest into other it consists of some unseen risks that this investment will never be came back consequently it will have a harmony within the exchange relationship (Eisenberger et al., 1986).

Many definitions of trust are found in organizational behavior literature. Trust is usually an individual's as well as group's determination being susceptible to an additional party using the peace of mind that this afterwards party can be charitable, dependable, trustworthy (Hopkins \& Weathington, 2006). Trust is the determination of one party being susceptible to the actions involving an additional party using the expectation that this other party will perform a unique activity important to the particular trustor, in spite of the opportunity to keep track of as well as manage of which other party (Hoy \& Tschannen-Moran, 1999). Trust is important for both inter organizational and intra organizational human relationships (Gounaris, 2005) however relationship within organizations are generally remains consequently organizational trust is more preferable identified as intra organizational trust.

\section{Association between justice and trust}

Although all three forms of justice are interrelated but they have independent effect on employees work attitudes. Study shows procedural justice is strong forecaster of trust in an organization (Bidarian \& Jafari, 2012). Some other studies show that Interactional justice has some positive effect on trust in supervisor (Wong, 2012). However some other studies find that Perceived Procedural Justice has significant effect on trust in supervisor (Tulubas \& Celep, 2012). Researchers argue that distributive justice is only predictor of managerial trust and Interactional justice did not predict either type of trust (Hubbell \& Chory-Assad, 2005).

\section{Perceived Support Mediation}

Perceived organizational support is among one of the global belief of the employees that concern the degree to which an organization give value to the employee contributions and the responsibility which an employee feels towards the activities that are assigned to him other than his job description. Such feelings affect the employee's voluntary performance (Eisenberger et al., 1986). Fair treatment and POS are linked. When there is fairness in distribution of resources it will impact significantly on POS through the perception of employee in that regard that the organization cares for the wellbeing of the employee(Eisenberger et al., 1986). The following statement is also supported by the previous researchers (Allen, Shore, \& Griffeth, 2003). Adding to that they also said that there is significant relationship between organizational support and organizational justice. 
Studies found positive relationship between procedural justice and organizational support, significant in nature (Stinglhamber et al., 2006). Alongside there are other studies which shows the relationship between procedural justice and organizational support and both of these variables are positively related to the apparent organizational support (Loi, Hang-Yue, \& Foley, 2006).

Researchers added that perceived supervisory support is the employee's perception about their supervisor cares towards them and the supervisor appreciation to the contributions of his sub ordinates (Eisenberger et al., 1986). The support includes providing the resources and information that is needed by the employees or showing the concern for the employee wellbeing at the work place or getting along with an employee to make them feel belonged. Supervisory support is also described as the degree to which an employee feels that they are being looked after and supported by their supervisor. Organizational support theory is the foundation of PSS. According to Organizational support theory PSS is a thought arises from the employees' experience of positive behavior from representatives of the organization particularly from their direct supervisor (Shanock \& Eisenberger, 2006).

Some prior research supports the relationship of Interactional Justice and PSS. (DeConinck \& Johnson, 2009) find that Procedural Justice is positively related to perceived organizational support, interactional Justice is related to PSS and distributive Justice is not related to any type of support. There are several studies which display that organizational justice is positively related to perceive organizational.

POS is related to trust because support suggests to employees that they can rely on their supervisor or the organization (Ambrose \& Schminke, 2003). Two studies have empirically demonstrated a positive relationship between perceived support and trust in management. First focused on the role of POS (Whitener, 2001)and other focused on PSS (Neves \& Caetano, 2006). PSS partly mediate effect of Interactional justice and supervisory trust (Stinglhamber et al., 2006). However few other studies show that all the three forms of justice have positive and significant relationship with PSS (Bostanci, 2013).

For the relationship of these variables with trust there are also different views of researchers. So we can conclude that different types of organizational justice have different independent effects on organizational and managerial trust as well as partially or fully mediated by POS and PSS. The fact to our knowledge there are only few studies (Stinglhamber et al., 2006) and (DeConinck, 2010) studying these variables in one model is astonishing and gives a clear indication for further study.

\section{Conceptual Framework}

Following figure reflects the relationship among research variables used in this research. Distributive, Interactional and Procedural justice are the Independent variables and Organizational Trust and Supervisory Trust are the dependent variables. Organizational Support and Supervisory Trust acts as mediator of the research and mediates the relationship of organizational justice dimensions and organizational and supervisory trust. Diagrammatic representation of the proposed relationships are shown in figure 1 


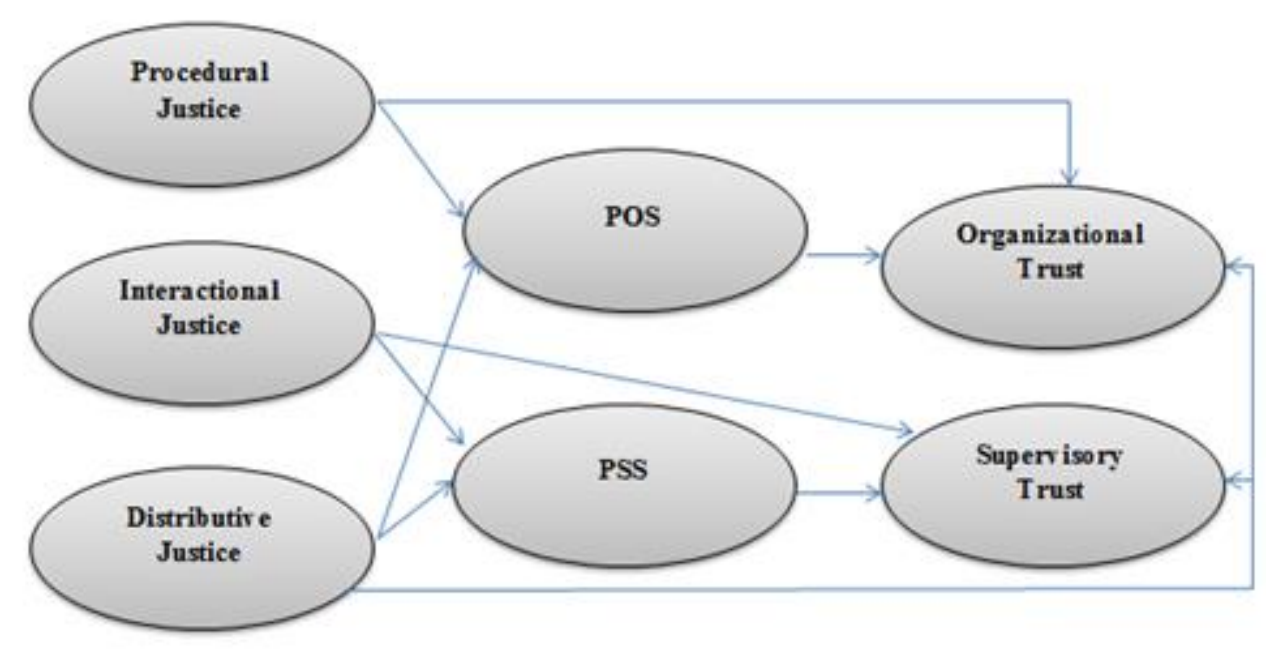

Figure 1 - Conceptual framework of the study

In the light of preceding conceptual framework, the researcher has formulated following hypotheses.

H1 (a): The relationship between distributive justice and organizational trust is positive.

H1 (b): The relationship between procedural justice and organizational trust is positive.

H1 (c): The relationship between interactional justice and organizational trust is positive.

H2 (a): The relationship between distributive justice and supervisory trust is positive and significant.

H2 (b): The relationship between Procedural justice and supervisory trust is positive and significant.

H2 (c): The relationship between Interactional justice and supervisory trust is positive and significant.

H3 (a): Perceived Organizational Support mediates the relation between distributive justice and organizational trust.

H3 (b): Perceived Organizational Support mediates the relation between procedural justice and organizational trust.

H3 (c): Perceived Supervisory Support mediates the relation between Interactional justice and supervisory trust.

H3 (d): Perceived Supervisory Support mediates the relation between distributive justice and supervisory trust.

\section{Research Design}

\section{Sampling Technique}

For this particular study the researcher employed multistage stratified sampling technique. Working population for the study consists of total 17 universities of Rawalpindi and Islamabad. I have randomly selected four private universities and eight public sector universities. So, on the basis of stratified sampling, total 12 universities were selected. Faculty members comprising of Professors, Assistant professor, Lecturers and Associate professor and of both private and public universities were the targeted for this study.

Twenty respondents were chosen from each university based on convenience, which made the sample size of 240 respondents. Out of which 170 were returned, with a response rate of $70 \%$. 


\section{Measurement}

All constructs were measured with scales adapted from the literature and measured on a five-point Likert-type scale where $1=$ strongly disagree and $5=$ strongly agree.

\section{Distributive Justice}

Distributive justice was measured using the six-item scale developed by previous researchers (Price \& Price, 2006).

\section{Procedural Justice}

Moorman's (1991) justice 6 items scale was used to measure the procedural justice. Same scale was used by (Williams et al., 2002).

\section{Interactional Justice}

A 6-item scale adapted from the study by Moorman (1991) was used to measure the Interactional Justice. Items of interactional justice were focused on the interpersonal behavior of the HoD by asking whether head of department was kind and considerate, respectful of employee rights, and truthful.

\section{Perceived Organizational Support (POS)}

To assess the perception of an employee reflecting that they are given value and their opinion is considered important and that the organization cares about their welfare, some researchers have recommended using a short version of POS because this may enhance the willingness of respondents to complete questionnaires (Masterson et al., 2000). Thus I selected four high-loading items from the Survey of Perceived Organizational Support (Items 4, 10, 17, and 23, with factor. Loadings of .74, .80, .80, .84 respectively.

\section{Perceived Supervisory Support (PSS)}

To measure the perception of the employees in regards of their supervisors valuing the contribution they made and an attitude of care towards the wellbeing of the employees, I applied a similar logic and used the four items with highest loading from the SPOS and replaced organization with supervisor (Shanock \& Eisenberger, 2006; Stinglhamber et al., 2006). Items.. 8.., 9.., 25.., and 27.., with factor loadings of .74.., .83.., .82.., and .76.., respectively.

\section{Organizational Trust}

Trust in the organization was assessed by seven items adapted from the scale that was developed by Gabarro and Athos (1978) and used in other studies (Aryee, Budhwar, \& Chen, 2002).

\section{Supervisor Trust}

To review employees' level of trust that they show in supervisor, six-item scale which is based on cognition trust was used (McAllister, 1995). Same scale was used by (Ambrose \& Schminke, 2003; DeConinck, 2010; Stinglhamber et al., 2006).

\section{Data Analysis}

To validate results of this study, various statistical tools and techniques were employed. Cronbach's alpha was employed to determined reliability of measures. The relationship between the variables was determined by employing the test of bivariate Pearson correlation

To analyze impact of independent variables on a dependent variable regression test was performed. There were three Dependent variables, two independent variables and two mediating variables. Regression analysis also shows the fitness of model with the value of R square. Hayes multiple mediation process (2013) has been used in SPSS 21 to test the direct and indirect effect of predictor variables on outcome variables. 
Majority of the respondents were females $(66 \%)$ and rests were males. Participants ranged from 23 to 53 years of age with a mean age of 30 years having a mean experience of 4 years as shown in table $2.86 \%$ respondents were single and $14 \%$ were married. The education level of the respondents shows that $27 \%$ respondents are Master's Degree holders (16 years), $47 \%$ having M. Phil degree (18 years), 23\% having doctorate degree and only $3 \%$ having post doc.

Cronbach's Alpha was used to assess the internal reliability. Analysis shows moderate to high reliability of the coefficients for the scales that were used for this research, the alpha value from 0.70 (Supervisory Trust) to 0.93 (PSS). The alpha value scores from 0.64 to 0.89 are quite acceptable in social sciences research (Choudhry, 2009). The alpha value of the Distributive Justice is 0.90 , Procedural Justice is 0.91 and of Interactional justice is 0.86 . Similarly alpha values calculated for POS and Organizational Trust are 0.71 and 0.87 respectively. The reliability for 39 items is 0.927 .

\section{Correlation}

The correlation of Distributive justice, Procedural justice, Interactional Justice, POS, PSS, Organizational Trust and Supervisory Trust is shown in table 1.

Table 1 - Correlation matrix

\begin{tabular}{|c|c|c|c|c|c|c|c|c|}
\hline & & DJ & PJ & IJ & POS & PSS & OT & ST \\
\hline \multirow[t]{2}{*}{ DJ } & $\begin{array}{l}\text { Pearson Correlation } \\
\text { Sig. (2-tailed) }\end{array}$ & 1 & & & & & & \\
\hline & $\mathrm{N}$ & 170 & & & & & & \\
\hline \multirow[t]{3}{*}{ PJ } & Pearson Correlation & $.635^{* *}$ & 1 & & & & & \\
\hline & Sig. (2-tailed) & .000 & & & & & & \\
\hline & $\mathrm{N}$ & 170 & 170 & & & & & \\
\hline \multirow[t]{3}{*}{ IJ } & Pearson Correlation & $.241^{* *}$ & $.385^{* *}$ & 1 & & & & \\
\hline & Sig. (2-tailed) & .002 & .000 & & & & & \\
\hline & $\mathrm{N}$ & 170 & 170 & 170 & & & & \\
\hline \multirow[t]{2}{*}{ POS } & Pearson Correlation & $.297^{* *}$ & $.596^{* *}$ & $.5^{23} 3^{* *}$ & 1 & & & \\
\hline & $\begin{array}{c}\text { Sig. (2-tailed) } \\
\mathrm{N}\end{array}$ & $\begin{array}{l}.000 \\
170\end{array}$ & $\begin{array}{l}.000 \\
170\end{array}$ & $\begin{array}{l}.000 \\
170\end{array}$ & 170 & & & \\
\hline \multirow[t]{3}{*}{ PSS } & Pearson Correlation & $.334^{* *}$ & $.357^{* *}$ & $.841^{* *}$ & $.438^{* *}$ & 1 & & \\
\hline & Sig. (2-tailed) & .000 & .000 & .000 & .000 & & & \\
\hline & $\mathrm{N}$ & 170 & 170 & 170 & 170 & 170 & & \\
\hline \multirow[t]{3}{*}{ OT } & Pearson Correlation & $.438^{* *}$ & $.651^{* *}$ & $.583^{* *}$ & $.550^{* *}$ & $.473^{* *}$ & 1 & \\
\hline & Sig. (2-tailed) & . 000 & .000 & .000 & .000 & .000 & & \\
\hline & $\mathrm{N}$ & 170 & 170 & 170 & 170 & 170 & 170 & \\
\hline \multirow{3}{*}{ ST } & Pearson Correlation & $.455^{* *}$ & $.599^{* *}$ & $.691^{* *}$ & $.749^{* *}$ & $.693^{* *}$ & $.549^{* *}$ & 1 \\
\hline & Sig. (2-tailed) & .000 & .000 & .000 & .000 & .000 & .000 & \\
\hline & $\mathrm{N}$ & 170 & 170 & 170 & 170 & 170 & 170 & 170 \\
\hline
\end{tabular}

**. Correlation is significant at the 0.01 level (2-tailed).

From the analysis it is noted that Distributive Justice is positively but moderately correlated to Organizational Trust $(\mathrm{r}=0.438, \mathrm{p}<0.01)$. So $\mathrm{H} 1$ of the study which states that, "there is positive relationship between Distributive justice and organizational trust" is accepted. It is also noted Distributive Justice and Supervisory Trust is also moderately correlated and value of $\mathrm{r}$ is 0.455 , and also significant at $\mathrm{p}<0.01)$. So H2a of the study 
which states that, "Distributive justice has positive and significant relationship with supervisory trust" is also accepted.

It is also noted that Procedural Justice is also positively and moderately related to both Organizational Trust $(\mathrm{r}=.651, \mathrm{p}<0.01)$ and Supervisory Trust $(\mathrm{r}=.599, \mathrm{p}<0.01)$. So we accept H1b and H2b.

Relationship of Interactional Justice with Organizational Trust is also positive and significant $(\mathrm{r}=.583, \mathrm{p}<0.01)$. So accepted H1c which is, "there is positive relationship between Interactional justice and organizational trust", but with Supervisor Support it is little strongly positive having $\mathrm{r}$ is 0.749 at $\mathrm{p}<0.01$. So H2c which states that, "Interactional justice has positive and significant relationship with supervisory trust" is accepted.

The results of correlation analysis show that Organizational Trust has positive relationship with Distributive, Procedural and Interactional Justice. These results provide prove for $\mathrm{H} 1 \mathrm{a}, \mathrm{H} 1 \mathrm{~b}$ and H1c. These results of this study are similar to some prior findings (DeConinck, 2010; Stinglhamber et al., 2006). Results also provide initial support that all the three dimensions of justice have significant positive relations with supervisory trust. So H2a, H2b and H2c are also accepted. It is also noted that all the three dimensions of Organizational Justice are positively related to Perceived Organizational Support.

It is of great interest that correlation among particular focus such as the organization and supervisor is stronger than the correlation found in the foci. For example it is seen that the relationship of procedural justice is strongly associated with POS having correlation value $r=0.596$ than with PSS having $r=.357$. Results also show that it is more strongly associated with trust in organization than trust in supervisor, $r=0.651$ and 0.599 , respectively. Results are similar to the findings of previous studies (Stinglhamber et al., 2006). The obtained results are in accordance with our hypotheses.

\section{Regression Analysis}

To analyze the impact of independent variables on a dependent variable regression test was performed. Study used three independent variable, two dependent and two mediation variables. Regression analysis also shows the fitness of model with the value of $\mathrm{R}$ square.

Hypotheses are tested by the regression analysis technique which is used to determine the effect independent variable has on dependent variable. Considering effect of Distributive, Procedural and Interactional Justice on Organizational Trust it is significant at 0.000 level which is considered quite high, as shown in table 2.

Table 2 - Regression analysis of DJ, PJ, IJ with OT

\begin{tabular}{|c|c|c|c|c|c|c|c|}
\hline No. & & Test & $\boldsymbol{\beta}$ & t & $\mathbf{R}^{2}$ & Adjusted $\mathbf{R}^{2}$ & F Stat \\
\hline 1 & DJ & $\longrightarrow \mathrm{OT}$ & .118 & $2.315 * * *$ & & & \\
\hline 2 & PJ & $\longrightarrow \mathrm{OT}$ & .473 & $6.709 * * *$ & & & \\
\hline 3 & IJ & $\longrightarrow \mathrm{OT}$ & .390 & $6.956 * * *$ & .555 & .547 & $68.952 * * *$ \\
\hline
\end{tabular}

Note: DJ=Distributive Justice, PJ Procedural Justice, IJ=Interactional Justice, OT $=$ Organizational Trust ${ }^{*} \mathrm{p}<0.05,{ }^{* *} \mathrm{p}<0.01, * * * \mathrm{p}<0.01$

In this case, I have tested three hypotheses: these are as follow: H1a: DJ has a direct and positive effect on OT, H1b: PJ has positive relationship with OT, H1c: IJ has positive relationship with OT.

The above table shows that value of $\mathrm{R}$ square is 0.547 . This shows that $54.7 \%$ variation in the OT is being explained by all independent variables. P-value is (.000) which means this relationship is also highly significant and we have accepted H1a, H1b, H1c. Beta values show the variation in dependent variables due to change in independent variables. Model fitness is confirmed by F-value $=68.952$. 
Then regression analysis for $\mathrm{H} 2 \mathrm{a}, \mathrm{H} 2 \mathrm{~b}$ and $\mathrm{H} 2 \mathrm{c}$ were conducted, results shown in table 3 .

Table 3 - Regression analysis of DJ, PJ, IJ with ST

\begin{tabular}{|c|c|c|c|c|c|c|c|}
\hline No. & & Test & $\beta$ & $\mathrm{t}$ & $\mathrm{R}^{2}$ & Adjusted $\mathrm{R}^{2}$ & F Stat \\
\hline 1 & DJ & $\longrightarrow \mathrm{ST}$ & .129 & $2.079 *$ & & & \\
\hline 2 & PJ & $\longrightarrow \mathrm{ST}$ & .308 & $4.717 * *$ & & & \\
\hline 3 & IJ & $\longrightarrow \mathrm{ST}$ & .541 & $10.406 * *$ & .617 & .611 & $89.320 * *$ \\
\hline
\end{tabular}

Note: DJ=Distributive Justice, PJ Procedural Justice, IJ=Interactional Justice, ST= Supervisory Trust ${ }^{*} \mathrm{p}<0.05,{ }^{* *} \mathrm{p}<0.01$

The above table shows that value of $\mathrm{R}$ square is 0.617 . This shows that $61.7 \%$ variation in the ST is being explained by all independent variables. P-value is (.000) which means this relationship is also highly significant and we have accepted $\mathrm{H} 2 \mathrm{a}, \mathrm{H} 2 \mathrm{~b}, \mathrm{H} 2 \mathrm{c}$, which states that there is positive relationship between Distributive, Procedural and Interactional Justice respectively. Beta values show the variation in dependent variables due to change in independent variables. Model fitness is confirmed by F-value $=89.320$.

\section{Mediation Analysis}

Hayes (2013) has been used in SPSS 21 to test the direct and indirect effect of predictor variables on outcome variables, Hayes explained that the mediation models can be explained in model templates. Therefore, researcher has tested mediation on Process Models 4.

\section{Mediation of POS with DJ and OT}

Table 4 - POS as a Mediator for Distributive Justice and Organizational Trust

\begin{tabular}{|c|c|c|c|c|c|c|}
\hline Steps & Test & $\boldsymbol{\beta}$ & $\mathbf{t}$ & sig & R square & F Stat \\
\hline \multirow[t]{2}{*}{1} & $\mathrm{DJ} \longrightarrow \mathrm{POS}$ & .2448 & 4.0316 & .000 & .0882 & 16.2536 \\
\hline & $\mathrm{POS} \longrightarrow \mathrm{OT}$ & .4814 & 7.2546 & .000 & .3855 & 52.3833 \\
\hline 2 & $\mathrm{DJ} \longrightarrow \mathrm{OT}$ & .2592 & 4.7401 & .000 & .3855 & 52.3833 \\
\hline
\end{tabular}

In this case, we have tested two hypotheses: these are as follow: H1a: DJ has a direct and positive effect on OT and H3a: POS mediates the relationship between DJ and OT.

Step 1: The above table shows that value of $\mathrm{R}$ square is 0.0882 . This shows that $8.82 \%$ variation in the POS is being explained by DJ. P-value is (.000) which means this relationship is also highly significant. DJ is regressed on the mediating variable which is POS was also significant $(\beta=.24$, $\mathrm{t}$-value $=4.0316, \mathrm{p}=<.000)$. It shows that DJ have a significant effect on the POS. Model fitness is confirmed by F-value $=16.2536$.

Step 2: First, in step 2 of the mediation process showed that the mediator (POS), controlling for DJ, thus, beta value $\beta=.4814$, $\mathrm{t}$-value $=7.2546$ is significant at $\mathrm{p}$-value $=.000$. The $\mathrm{R}$ square result $\left(\mathrm{R}^{2}=0.38\right)$ reveal that the POS has accounted for $38.0 \%$ variation in OT. The $\mathrm{F}=52.38$ confirms the model fitness. Thus POS relationship with OT is accepted and positive.

Second, controlling for MV (POS), Distributive Justice was significant predictor of Organizational Trust, $\beta=$ .2592 , $\mathrm{t}$-value $=4.74$, $\mathrm{p}$-value $=.000$. The F-value is 52.3833 , confirms the models fitness and $\mathrm{r}$ square result 0.38 , which shows that $38 \%$ variation in Dependent variable is being explained by model. Hence H1a and H3a are both supported. From the above results it can be safely concluded that Perceived Organizational Support partially mediates the relation between Distributive Justice and organizational Trust. 
Table 5 - POS as a Mediator for Distributive Justice and Organizational Trust: Total, Direct, And Indirect Effects

\section{Total effect of $X$ on $Y$}

\begin{tabular}{llll}
\hline Effect & SE & $\mathrm{t}$ & $\mathrm{p}$ \\
.3771 & .0597 & 6.3152 & .0000 \\
Direct effect of $\mathbf{X}$ on $\mathbf{Y}$ & & \\
Effect & SE & $\mathrm{t}$ & $\mathrm{p}$ \\
.2592 & .0547 & 4.7401 & .0000 \\
Indirect effect of X on Y (POS) & & \\
Effect & Boot SE & Boot LLCI & Boot ULCI \\
.1178 & .0343 & .0572 & .1986
\end{tabular}

Mediation Effect $=0.31$

Normal theory tests for indirect effect

$\begin{array}{llll}\text { Effect } & \text { se } & \mathrm{Z} & \mathrm{p} \\ .1178 & .0337 & 3.4987 & .0005\end{array}$

The results indicate that total effect of Distributive Justice and POS on OT is significant $\beta=.3771, \mathrm{t}=6.3152 \mathrm{CI}$ [0.25: 0.49]. The direct effect of Distributive Justice on OT is also significant $\beta=.259, t=4.7401$ CI [0.15: 0.36].

The results of indirect effect fully supported that POS mediates the relationship between Distributive Justice and OT, $\beta=.117$, CI [0.057: 0. 198].

The results show that there is 30\% mediation of POS between Distributive Justice and OT. The Sobal test also confirms the mediation results indicate that POS plays a mediating role between Distributive Justice and OT of the faculty members $(\beta=0.117, \mathrm{Z}=3.49, \mathrm{p}<0.05)$.

\section{Mediation of POS with PJ and OT}

Table 6 - POS as a Mediator for Procedural Justice and Organizational Trust

\begin{tabular}{|c|c|c|c|c|c|c|}
\hline \multirow{3}{*}{$\begin{array}{l}\text { Steps } \\
1\end{array}$} & Test & $\boldsymbol{\beta}$ & $\mathbf{T}$ & sig & R square & F Stat \\
\hline & $\mathrm{PJ} \longrightarrow \mathrm{POS}$ & .4868 & 9.6195 & .000 & .3552 & 92.5352 \\
\hline & $\mathrm{POS} \longrightarrow \mathrm{OT}$ & .2628 & 7.5688 & .000 & .4648 & 72.5212 \\
\hline 2 & $\mathrm{PJ} \longrightarrow \mathrm{OT}$ & .4277 & 7.1097 & .000 & .4648 & 72.5212 \\
\hline
\end{tabular}

In this case, we have tested two hypotheses: these are as follow: H1b: PJ has a direct and positive effect on OT and H3B: POS mediates the relationship between PJ and OT.

Step 1: The above table shows that value of $\mathrm{R}$ square is 0.3552 . This shows that $35.52 \%$ variation in the POS is being explained by PJ. P-value is (.000) which means this relationship is also highly significant. PJ is regressed on the mediating variable which is POS was also significant $(\beta=.48$, $\mathrm{t}$-value $=9.6195, \mathrm{p}=<.000)$. It shows that PJ have a significant effect on the POS. Model fitness is confirmed by F-value $=92.5352$.

Step 2: First, in step 2 of the mediation process showed that the mediator (POS), controlling for PJ, thus, beta value $\beta=.2628$, $\mathrm{t}$-value $=7.5688$ is significant at $\mathrm{p}$-value $=.000$. The $\mathrm{R}$ square result $\left(\mathrm{R}^{2}=0.46\right)$ reveal that the POS has accounted for $46.0 \%$ variation in OT. The $\mathrm{F}=72.52$ confirms the model fitness. Thus POS relationship with OT is accepted and positive.

Second, controlling for MV (POS), Procedural Justice was significant predictor of Organizational Trust, $\beta=$ $.4277, \mathrm{t}$-value $=7.1097, \mathrm{p}$-value $=.000$. The $\mathrm{F}$-value is 72.52 , confirms the models fitness and $\mathrm{r}$ square result 0.46 , which shows that $46 \%$ variation in Dependent variable is being explained by model. Hence H1b and H3b 
are both supported. From the above results it can be safely concluded that Perceived Organizational Support partially mediates the relation between Procedural Justice and organizational Trust.

Table 7 - POS as a Mediator for Procedural Justice and Organizational Trust: Total, Direct, And Indirect Effects

\section{Total effect of $X$ on $\mathbf{Y}$}

\begin{tabular}{llllll}
\hline Effect & $\mathrm{SE}$ & $\mathrm{t}$ & $\mathrm{p}$ & LLCI & ULCI \\
.5556 & .0500 & 11.1206 & .0000 & .4570 & .6542
\end{tabular}

Direct effect of $\mathrm{X}$ on $\mathrm{Y}$

$\begin{array}{llllll}\text { Effect } & \mathrm{SE} & \mathrm{t} & \mathrm{p} & \text { LLCI } & \text { ULCI } \\ .4277 & .0602 & 7.1097 & .0000 & .3089 & .5464\end{array}$

\section{Indirect effect of $\mathrm{X}$ on Y (POS)}

$\begin{array}{llll}\text { Effect } & \text { Boot SE } & \text { Boot LLCI } & \text { Boot ULCI } \\ .1279 & .0452 & .0431 & .2235\end{array}$

Mediation

Effect $=0.23$

Normal theory tests for indirect effect

\begin{tabular}{llll} 
Effect & se & $\mathrm{Z}$ & $\mathrm{p}$ \\
.1279 & .0384 & 3.3302 & .0009 \\
\hline
\end{tabular}

\section{Mediation of PSS with IJ and ST}

Table 8 - PSS as a Mediator for Interactional Justice and Supervisory Trust

\begin{tabular}{|c|c|c|c|c|c|c|}
\hline Steps & Test & B & $\mathbf{T}$ & sig & R square & F Stat \\
\hline 1 & IJ $\longrightarrow$ PSS & .9503 & 20.1214 & .000 & .7067 & 404.8720 \\
\hline & $\mathrm{PSS} \longrightarrow \mathrm{ST}$ & .2840 & 3.8715 & .000 & .7207 & 90.7004 \\
\hline 2 & $\mathrm{IJ} \longrightarrow \mathrm{ST}$ & .3095 & 3.7312 & .000 & .7207 & 90.7004 \\
\hline
\end{tabular}

In this case, we have tested two hypotheses: these are as follow: H2c: IJ has a direct and positive effect on ST and H3c: PSS mediates the relationship between IJ and ST.

Step 1: The above table shows that value of $\mathrm{R}$ square is 0.7067 . This shows that $70.67 \%$ variation in the PSS is being explained by IJ. P-value is (.000) which means this relationship is also highly significant. IJ is regressed on the mediating variable which is PSS was also significant $(\beta=.95$, $\mathrm{t}$-value $=20.1214, \mathrm{p}=<.000)$. It shows that IJ have a significant effect on the PSS. Model fitness is confirmed by F-value $=404.8720$.

Step 2: First, in step 2 of the mediation process showed that the mediator (PSS), controlling for IJ, thus, beta value $\beta=.2840$, $t$-value $=3.8715$ is significant at $\mathrm{p}$-value $=.000$. The $\mathrm{R}$ square result $\left(\mathrm{R}^{2}=0.72\right)$ reveal that the PSS has accounted for $72.0 \%$ variation in ST. The F $=90.70$ confirms the model fitness. Thus PSS relationship with ST is accepted and positive.

Second, controlling for MV (PSS), Interactional Justice was significant predictor of Supervisory Trust, $\beta=$ .3095 , $\mathrm{t}$-value $=3.7312$, $\mathrm{p}$-value $=.000$. The F-value is 90.70 , confirms the models fitness and $\mathrm{r}$ square result 0.52 , which shows that $52 \%$ variation in Dependent variable is being explained by model. Hence H2c and H3c are both supported. From the above results it can be safely concluded Perceived Supervisor Support partially mediates relation among Interactional Justice and Supervisory Trust. 
Table 9 - PSS as a Mediator for Interactional Justice and Supervisory Trust: Total, Direct, And Indirect Effects

\section{Total effect of $X$ on $\mathbf{Y}$}

\begin{tabular}{llllll}
\hline Effect & $\mathrm{SE}$ & $\mathrm{t}$ & $\mathrm{p}$ & LLCI & ULCI \\
.5794 & .0467 & 12.3944 & .0000 & .4871 & .6717
\end{tabular}

\section{Direct effect of $\mathrm{X}$ on $\mathrm{Y}$}

$\begin{array}{llllll}\text { Effect } & \mathrm{SE} & \mathrm{t} & \mathrm{p} & \text { LLCI } & \text { ULCI } \\ .3095 & .0829 & 3.7312 & .0003 & .1457 & .4732\end{array}$

\section{Indirect effect of X on Y (PSS)}

$\begin{array}{llll}\text { Effect } & \text { Boot SE } & \text { Boot LLCI } & \text { Boot ULCI } \\ .2699 & .0599 & .1563 & .3871\end{array}$

Mediation Effect $=0.46$

\section{Normal theory tests for indirect effect}

\begin{tabular}{llll} 
Effect & se & $\mathrm{Z}$ & $\mathrm{p}$ \\
.2699 & .0711 & 3.7972 & .0001 \\
\hline
\end{tabular}

\section{Mediation of PSS with DJ and ST}

Table 10 - PSS as a Mediator for Distributive Justice and Supervisory Trust

\begin{tabular}{lllllll}
\hline Steps & Test & $\boldsymbol{\beta}$ & T & sig & R square & F Stat \\
\hline 1 & DJ $\longrightarrow$ PSS & .3249 & 4.5929 & .000 & .1116 & 21.0945 \\
& PSS $\longrightarrow$ ST & .4518 & 10.9065 & .000 & .5370 & 96.8402 \\
2 & DJ $\longrightarrow$ ST & .1815 & 4.5054 & .000 & .5370 & 96.8402
\end{tabular}

In this case, we have tested two hypotheses: these are as follow: H2a: DJ has a direct and positive effect on ST and H3d: PSS mediates the relationship between DJ and ST.

Step 1: The above table shows that value of $\mathrm{R}$ square is 0.1116 . This shows that $11 \%$ variation in the PSS is being explained by DJ. P-value is (.000) which means this relationship is also highly significant. DJ is regressed on the mediating variable which is PSS was also significant $(\beta=.32$, $\mathrm{t}$-value $=4.5929, \mathrm{p}=<.000)$. It shows that DJ have a significant effect on the PSS. Model fitness is confirmed by F-value $=21.0945$.

Step 2: First, in step 2 of the mediation process showed that the mediator (PSS), controlling for DJ, thus, beta value $\beta=.4518, t$-value $=10.9065$ is significant at $\mathrm{p}$-value $=.000$. The $\mathrm{R}$ square result $\left(\mathrm{R}^{2}=0.53\right)$ reveal that the PSS has accounted for $53.0 \%$ variation in ST. The F= 96.84 confirms the model fitness. Thus PSS relationship with ST is accepted and positive.

Second, controlling for MV (PSS), Distributive Justice was significant predictor of Supervisory Trust, $\beta=.1815$, $\mathrm{t}$-value $=4.5054, \mathrm{p}$-value $=.000$. The F-value is 96.84 , confirms the models fitness and $\mathrm{r}$ square result 0.53 , which shows that $53 \%$ variation in Dependent variable is being explained by model. Hence H2a and H3d are both supported. From the above results it can be safely concluded Perceived Supervisor Support partially mediates relation among Distributive Justice and Supervisory Trust.

Table 11 - PSS as a Mediator for Distributive Justice and Supervisory Trust: Total, Direct, And Indirect Effects

\section{Total effect of $X$ on $Y$}

\begin{tabular}{llllll}
\hline Effect & SE & $\mathrm{t}$ & $\mathrm{p}$ & LLCI & ULCI \\
.3283 & .0496 & 6.6260 & .0000 & .2305 & .4262
\end{tabular}

\section{Direct effect of $\mathrm{X}$ on $\mathrm{Y}$}




\begin{tabular}{llllll}
\hline Effect & SE & $\mathrm{t}$ & $\mathrm{p}$ & LLCI & ULCI \\
.1815 & .0403 & 4.5054 & .0000 & .1020 & .2611
\end{tabular}

\section{Indirect effect of X on Y (PSS)}

$\begin{array}{llll}\text { Effect } & \text { Boot SE } & \text { Boot LLCI } & \text { Boot ULCI } \\ .1468 & .0443 & .0633 & .2411\end{array}$

Mediation Effect $=0.44$

Normal theory tests for indirect effect

$\begin{array}{llll}\text { Effect } & \mathrm{se} & \mathrm{Z} & \mathrm{p} \\ .1468 & .0348 & 4.2178 & .0000\end{array}$

\section{Conclusion}

In this study, we investigated how employees' perceptions of organizational justice, support affect employees trust level. After conducting the research it can be said that the outcome has various significant implications.

This research validated and further elaborated the results of previous research in the area. Our hypotheses were supported. This study revealed that POS mediates the relationship of distributive justice and organizational trust and interactional justice is associated with PSS and trust in supervisors, which confirms the previous research. Procedural justice is an antecedent to OT directly and indirectly through POS, which validates previous research (DeConinck, 2010; Stinglhamber et al., 2006). Hence, it can be suggested that employment affiliation is a function of employees' connections with the whole organization and the supervisor.

In most of the prior studies Distributive Justice is not included, but the results of this study reflected the significance distributive justice has on employees' perception in regards to support and trust. It is related to Supervisor Trust directly and indirectly by means of PSS and related Organizational Trust directly and indirectly through POS.

It was also revealed that Distributive justice and interactional justice are more important predictors for Supervisory Trust using PSS $\left(\mathrm{R}^{2}\right.$ Change $=53 \%$ and $72 \%$ respectively). The reason behind this can be that the evaluation of an employee of the interaction he/she has with the superior is dependent upon the interpersonal contact originating from their everyday one on one interaction with that individual. Therefore, evaluation of this process with the superior is mostly based on the character of the superior and their behavior at the workplace. Results of the study also revealed that procedural justice is more important predictor of OT $\left(\mathrm{R}^{2}=\right.$ $46.4 \%)$ as compare to distributive justice $\left(\mathrm{R}^{2}=38.5\right)$.

Results also revealed that has Distributive Justice is strongly associated to Supervisory Trust $\left(\mathrm{R}^{2}=53 \%\right)$ as compared to Organizational Trust $\left(\mathrm{R}^{2}=38.5 \%\right)$. Previous studies found that distributive justice perceptions may be associated with the person implementing and communicating decisions to employees, but not with the organization as a whole (Hubbell \& Chory-Assad, 2005).

It can be suggested using the results distributive justice is significant variable affecting the perceived support of an employee and trust that they have; hence it should be a part of any future research assessing these variables.

\section{Limitations and Future Research}

The research conducted provides various opportunities for any future research. As this particular research was first of its nature conducted in educational sector of Pakistan and consists of three elements of organizational justice, POS, PSS and trust, a need for further replication of this is needed. The obtained results confirmed that relationships between Organizational Justice, Support and Trust are important. So it becomes vital to 
understand why employees develop trust for their respective organization. It can also be suggested that by increasing perception of the justice in an organization level of support and trust can also be increased in the employees.

All empirical studies have limitations and this study is not an exception. The first most important limitation of the study is that data is collected from universities of Islamabad only. There are few researchers who believe that interactional justice only has two components. The first one being the treatment of people with utmost respect and integrity, and the second one involves the proper explanation of reasons behind a certain decisions (Niehoff \& Moorman, 1993). Further in upon this reason (Colquitt et al., 2001) has maintained that these components be treated as two distinct dimensions: first one being interpersonal justice (the degree of which an individual is treated with respect) and the second one related to explanation of decisions made at work place known as informational justice (Greenberg, 2001). So it is recommended to use the four factor taxonomy to be used for any future research on this topic.

Some constructs were shortened before they were used in the particular theoretical mode. Specifically POS, PSS, and trust, were measured using appropriate items depending on the material and the obtained results of previous work on the subject. Although shorten version of the survey is favorable in achieving higher response rate, but the possibility of leaving out some relevant information that is essential for understanding the question cannot be ruled out. It is also recommended that any future research should take into account the possibility of issues that can be faced due to change of original construct to measure the variables.

\section{Practical Implications:}

To conclude it can be said that this study give evidence various kinds of justice has effect on different levels. The practical aspect of this research is the findings that the leaders, superiors managers and individuals who represent the organization need to have training on the various type of justice that prevail in the organization and how the effect various elements in work place and what could be their consequences. It was also stressed to enhance the level of trust at various organizational levels. Higher the level of trust the higher the performance of the team can be, and the higher level of organizational trust leads to interdepartmental trust and among the teams for the common purpose of promoting welfare of the organization. Hence the representatives of the organization can reap benefits of training by implanting various justice rules.

Funding: This research received no external funding.

Conflicts of Interest: The authors declare no conflict of interest.

\section{References}

Allen, D. G., Shore, L. M., \& Griffeth, R. W. (2003). The Role of Perceived Organizational Support and Supportive Human Resource Practices in the Turnover Process. Journal of Management, 29(1), 99-118. doi:10.1177/014920630302900107

Ambrose, M. L. (2002). Contemporary justice research: A new look at familiar questions. Organizational Behavior and Human Decision Processes, 89(1), 803-812. doi:10.1016/S0749-5978(02)00030-4

Ambrose, M. L., \& Schminke, M. (2003). Organization structure as a moderator of the relationship between procedural justice, interactional justice, perceived organizational support, and supervisory trust. Journal of Applied Psychology, 88(2), 295-305. doi:10.1037/0021-9010.88.2.295

Aryee, S., Budhwar, P. S., \& Chen, Z. X. (2002). Trust as a mediator of the relationship between organizational justice and work outcomes: test of a social exchange model. Journal of Organizational Behavior, 23(3), 267-285. doi:10.1002/job.138 
Bakhshi, A., Kumar, K., \& Rani, E. (2009). Organizational justice perceptions as predictor of job satisfaction and organization commitment. International Journal of Business and Management, 4(9), p145. doi:10.5539/ijbm.v4n9p145

Bidarian, S., \& Jafari, P. (2012). The Relationship Between Organizational Justice and Organizational Trust. Procedia - Social and Behavioral Sciences, 47, 1622-1626. doi:https://doi.org/10.1016/j.sbspro.2012.06.873

Bies, R. J., \& Shapiro, D. L. (1987). Interactional fairness judgments: The influence of causal accounts. Social Justice Research, 1(2), 199-218. doi:10.1007/BF01048016

Blau, P. M. (1964). Justice in Social Exchange. Sociological Inquiry, 34(2), 193-206. doi:10.1111/j.1475682X.1964.tb00583.x

Bostanci, A. B. J. I. J. o. S. S. (2013). The Mediator Role of Perceived Administrator Support in the Relationship between Teachers' Perceptions of Organizational Justice and Organizational Support. International Journal of Social Sciences and Education, 3(3).

Colquitt, J. A., Conlon, D. E., Wesson, M. J., Porter, C. O. L. H., \& Ng, K. Y. (2001). Justice at the millennium: A meta-analytic review of 25 years of organizational justice research. Journal of Applied Psychology, 86(3), 425-445. doi:10.1037/0021-9010.86.3.425

DeConinck, J. B. (2010). The effect of organizational justice, perceived organizational support, and perceived supervisor support on marketing employees' level of trust. Journal of Business Research, 63(12), 13491355. doi:10.1016/j.jbusres.2010.01.003

DeConinck, J. B., \& Johnson, J. T. (2009). The Effects of Perceived Supervisor Support, Perceived Organizational Support, and Organizational Justice on Turnover among Salespeople. Journal of Personal Selling \& Sales Management, 29(4), 333-350. doi:10.2753/PSS0885-3134290403

Eisenberger, R., Huntington, R., Hutchison, S., \& Sowa, D. (1986). Perceived organizational support. Journal of Applied Psychology, 71(3), 500-507. doi:10.1037/0021-9010.71.3.500

Ertürk, A. (2007). Increasing organizational citizenship behaviors of Turkish academicians: Mediating role of trust in supervisor on the relationship between organizational justice and citizenship behaviors. Journal of Managerial Psychology, 22(3), 257-270. doi:10.1108/02683940710733089

Folger, R., \& Konovsky, M. A. (1989). Effects of Procedural and Distributive Justice on Reactions to Pay Raise Decisions. Academy of Management Journal, 32(1), 115-130. doi:10.5465/256422

Gounaris, S. P. (2005). Trust and commitment influences on customer retention: insights from business-tobusiness services. Journal of Business Research, 58(2), 126-140. doi:10.1016/S0148-2963(03)00122-X

Greenberg, J. (1990). Organizational Justice: Yesterday, Today, and Tomorrow. Journal of Management, 16(2), 399-432. doi:10.1177/014920639001600208

Greenberg, J. (2001). STUDYING ORGANIZATIONAL JUSTICE CROSS-CULTURALLY: FUNDAMENTAL CHALLENGES. International Journal of Conflict Management, 12(4), 365-375. doi:10.1108/eb022864

Hopkins, S. M., \& Weathington, B. L. (2006). The Relationships Between Justice Perceptions, Trust, and Employee Attitudes in a Downsized Organization. The Journal of Psychology, 140(5), 477-498. doi:10.3200/JRLP.140.5.477-498

Hoy, W. K., \& Tschannen-Moran, M. (1999). Five Faces of Trust: An Empirical Confirmation in Urban Elementary Schools. Journal of School Leadership, 9(3), 184-208. doi:10.1177/105268469900900301

Hubbell, A. P., \& Chory-Assad, R. M. (2005). Motivating factors: perceptions of justice and their relationship with managerial and organizational trust. Communication Studies, 56(1), 47-70. doi:10.1080/0008957042000332241

Kurtessis, J. N., Eisenberger, R., Ford, M. T., Buffardi, L. C., Stewart, K. A., \& Adis, C. S. (2015). Perceived Organizational Support: A Meta-Analytic Evaluation of Organizational Support Theory. Journal of Management, 43(6), 1854-1884. doi:10.1177/0149206315575554 
Loi, R., Hang-Yue, N., \& Foley, S. (2006). Linking employees' justice perceptions to organizational commitment and intention to leave: The mediating role of perceived organizational support. Journal of Occupational and Organizational Psychology, 79(1), 101-120. doi:10.1348/096317905X39657

Maertz, C. P., Griffeth, R. W., Campbell, N. S., \& Allen, D. G. (2007). The effects of perceived organizational support and perceived supervisor support on employee turnover. Journal of Organizational Behavior, 28(8), 1059-1075. doi:10.1002/job.472

Masterson, S. S., Lewis, K., Goldman, B. M., \& Taylor, M. S. (2000). Integrating Justice and Social Exchange: The Differing Effects of Fair Procedures and Treatment on Work Relationships. Academy of Management Journal, 43(4), 738-748. doi:10.5465/1556364

McAllister, D. J. (1995). Affect- and Cognition-Based Trust as Foundations for Interpersonal Cooperation in Organizations. Academy of Management Journal, 38(1), 24-59. doi:10.5465/256727

Moliner, C., Martínez-Tur, V., Ramos, J., Peiró, J. M., \& Cropanzano, R. (2008). Organizational justice and extrarole customer service: The mediating role of well-being at work. European Journal of Work and Organizational Psychology, 17(3), 327-348. doi:10.1080/13594320701743616

Neves, P., \& Caetano, A. (2006). Social Exchange Processes in Organizational Change: The Roles of Trust and Control. Journal of Change Management, 6(4), 351-364. doi:10.1080/14697010601054008

Niehoff, B. P., \& Moorman, R. H. (1993). Justice as a Mediator of the Relationship Between Methods of Monitoring and Organizational Citizenship Behavior. Academy of Management Journal, 36(3), 527-556. doi: $10.5465 / 256591$

Noruzy, A., Shatery, K., Rezazadeh, A., \& Hatami-Shirkouhi, L. (2011). Investigation the relationship between organizational justice, and organizational citizenship behavior: The mediating role of perceived organizational support. Indian Journal of science and Technology4(7), 842-847.

Robbins, B. G. (2011). Neither government nor community alone: A test of state-centered models of generalized trust. Rationality and Society, 23(3), 304-346. doi:10.1177/1043463111404665

Roch, S. G., \& Shanock, L. R. (2006). Organizational Justice in an Exchange Framework: Clarifying Organizational Justice Distinctions. Journal of Management, 32(2), 299-322. doi:10.1177/0149206305280115

Shanock, L. R., \& Eisenberger, R. (2006). When supervisors feel supported: Relationships with subordinates' perceived supervisor support, perceived organizational support, and performance. Journal of Applied Psychology, 91 (3), 689-695. doi:10.1037/0021-9010.91.3.689

Sousa-Lima, M., Michel, J. W., \& Caetano, A. (2013). Clarifying the importance of trust in organizations as a component of effective work relationships: Trust in organizations. Journal of Applied Social Psychology, 43(2), 418-427. doi:10.1111/j.1559-1816.2013.01012.x

Stinglhamber, F., Cremer, D. D., \& Mercken, L. (2006). Perceived Support as a Mediator of the Relationship Between Justice and Trust: A Multiple Foci Approach. Group \& Organization Management, 31(4), 442468. doi:10.1177/1059601106286782

Tulubas, T., \& Celep, C. (2012). Effect of Perceived Procedural Justice on Faculty Members' Silence: The Mediating Role of Trust in Supervisor. Procedia - Social and Behavioral Sciences, 47, 1221-1231. doi:10.1016/j.sbspro.2012.06.804

Whitener, E. M. (2001). Do "high commitment" human resource practices affect employee commitment?: A cross-level analysis using hierarchical linear modeling. Journal of Management, 27(5), 515-535. doi:10.1177/014920630102700502

Zeinabadi, H., \& Rastegarpour, H. (2010). Factors affecting teacher trust in principal: testing the effect of transformational leadership and procedural justice. Procedia - Social and Behavioral Sciences, 5, 1004-1008. doi:10.1016/j.sbspro.2010.07.226 